\title{
"Serum Magnesium Level in Acute Myocardial Infarction: A Study in Rajshahi Medical College Hospital, Rajshahi, Bangladesh"
}

\author{
Md. Abdul Baset ${ }^{1 *}$, Md. Zahirul Haque ${ }^{2}$, Md. Azizul Hoque ${ }^{3}$, Shabyasachi Nath $^{4}$, Shah Mohammad \\ ${ }^{1}$ Junior Consultant (Medicine), Upazila Health Complex, Paba, Rajshahi, Bangladesh \\ ${ }^{2}$ Associate Professor, Department of Medicine, Rajshahi Medical College Hospital, Rajshahi, Bangladesh \\ ${ }^{3}$ Associate Professor and Head (Ex.), Department of Medicine, Rajshahi Medical College Hospital, Rajshahi, Bangladesh \\ ${ }^{4}$ Deputy Program Manager, Hospital Services Management, DGHS, Dhaka, Bangladesh \\ ${ }^{5}$ Junior Consultant (Obs \& Gynae), Pakundia Upazila Health Complex, Pakundia, Kishoreganj, Bangladesh
}

\begin{abstract}
DOI: $10.36348 /$ sjmps.2020.v06i01.020
\end{abstract}
| Received: 03.01.2020 | Accepted: 21.01.2020 | Published: 30.01.2020

*Corresponding author: Md. Abdul Baset

\section{Abstract}

Introduction: Magnesium $(\mathrm{Mg})$ is the second most common intracellular cation after potassium $(\mathrm{K})$. $\mathrm{Mg}$ is a cofactor in many enzyme systems in human cells and it has a predominant role in normal myocardial physiology. The role of magnesium in cardiovascular disease has received widespread attention. Magnesium has been implicated in the complications like arrhythmias in acute myocardial infarction. Objective: To know the serum magnesium level in patients with acute myocardial infarction and its relation with arrhythmia. Study design: Descriptive cross sectional study. Study place \& period: Department of Cardiology, Rajshahi Medical College Hospital, Rajshahi from July, 2013 to November, 2013. Subjects: 50 patients with acute myocardial infarction admitted to the Department of Cardiology, Rajshahi Medical College Hospital. Methods: Data was collected from patients of any age and both sexes with acute myocardial infarction as determined by clinical features, ECG evidence and biochemical report. Blood sample for estimation of serum magnesium level was collected as early as possible within 24 hours of admission and $5^{\text {th }}$ day of admission. After admission to CCU every patient was under continuous cardiac monitoring to see and record any arrhythmia within 5 days onset of symptoms. Results: A total of 50 patients of acute myocardial infarction were included during the study period. The male to female ratio in the study group was 3.17:1 and the maximum incidence of acute myocardial infarction was seen in $5^{\text {th }}$ and $6^{\text {th }}$ decade. The most common presenting symptom was chest pain which was present in all patients and was associated with sweat in $60 \%$ of patients and breathlessness in $64 \%$ of patients and palpitation in $50 \%$. In the study, the most common risk factor found was smoking (70\%) followed by diabetes $(36 \%)$ and hypertension (30\%). Anterior wall MI was found to be the most common type of MI (42\%). Arrhythmia developed in $(52 \%)$ patients and in majority $(57.7 \%)$ of with anterior wall MI. In the study group mean serum magnesium level in 50 patients on day-1 is $1.86 \pm 0.39$ and on Day-5 is $2.26 \pm 0.5$. Mean serum magnesium level in 26 patients with arrhythmia was $1.65 \pm 0.26$ on day- 1 and $1.98 \pm 0.25$ on day-5. In the study group, mean serum magnesium level in 24 patients without arrhythmia was $2.05 \pm 0.41$ on day- 1 and $2.48 \pm 0.52$ on day-5. The difference between the magnesium level in patients with arrhythmia and without arrhythmia is statically significant on both day- 1 and day-5 (p<0.001). PVC was the most common type (42.5\%) of arrhythmia. Conclusion: serum magnesium levels are significantly low in patients who develop arrhythmia in acute myocardial infarction.

Keywords: Coronary artery disease, acute myocardial infarction, serum magnesium level, arrhythmia.

Copyright @ 2020: This is an open-access article distributed under the terms of the Creative Commons Attribution license which permits unrestricted
use, distribution, and reproduction in any medium for non-commercial use (NonCommercial, or CC-BY-NC) provided the original author and source
are credited.

\section{INTRODUCTION}

Coronary artery disease (CAD) is the highest killer in developed countries and is now an emerging epidemic in developing countries including Bangladesh. During recent years, more than six million people worldwide died of Ischaemic heart disease, which was predicted to be the leading cause deaths all over the world [1]. A study showed that acute myocardial infarction (AMI) is the leading cause of death in Bangladesh in the $4^{\text {th }}$ decade of life [2]. So, in our population myocardial infarction emerged as a major killer and in the long run a major cause of morbidity also is becoming a significant burden on health care services in Bangladesh. In Bangladesh, the prevalence of CAD was estimated as $13 / 1000$ in 2004[3]. The role of magnesium in cardiovascular disease has received widespread attention. The relationship between 
hypomagnesemia and arrhythmias has been well documented. Several investigators have also noted the association between magnesium deficiency and coronary artery disease $[4,5]$. Magnesium $(\mathrm{Mg})$ is the second most common intracellular cation after potassium $(\mathrm{K})[6] . \mathrm{Mg}$ is a cofactor in more than 300 enzyme systems in human cells and it has a predominant role in normal myocardial physiology. Magnesium improves myocardial metabolism, inhibits calcium accumulation and myocardial cell death. It improves vascular tone, peripheral vascular resistance, after load and cardiac output, reduces cardiac arrhythmias and improves lipid metabolism. Magnesium also reduces vulnerability to oxygen derived free radicals, improves endothelial function and inhibits platelet function including platelet aggregation and adhesion [7]. Myocardial magnesium concentration in patients with sudden death due to ischemic heart disease was found to be very low [8]. These findings directly correlated with the resultant complications of myocardial infarction, such as arrhythmias. The reduction of infarct size with magnesium has profound research and clinical implications [9]. Hypomagnesemia is an important risk factor for post AMI complication. It has been reported in various international studies that the serum $\mathrm{Mg}$ level is not only low at admission in cases of AMI but also continues to fall even for days after the onset of AMI [10-12]. It is unknown however, if the low cardiac content precedes the myocardial infarction or is result of it. Hypomagnessemia is present in acute myocardial infarction (AMI) as shift of magnesium from extra cellular to intracellular compartments occur [13]. A number of clinical studies have shown a fall in the serum magnesium concentration within first 24 to 48 hours after myocardial infarction [14]. A study from Rajasthan tried to determine the prognostic significance of serum magnesium levels in acute MI. Serum magnesium was found to be significantly lowered on the first day and it gradually rose to normal value by the twenty first day [15]. One study of Dhaka showed that there is a significant lower serum $\mathrm{Mg}$ and $\mathrm{K}$ level in AMI than chronic IHD and fall of serum $\mathrm{Mg}$ immediately after AMI may be due to the catecholamine induced high FFA which causes bindings and precipitation of $\mathrm{Mg}$ into the cells, resulting in a sudden decrease in total plasma Mg level[16]. As reported recently, intracellular magnesium levels are reduced in patients with AMI. This deficiency is not adequately reflected in serum measurements, since magnesium is predominantly an intracellular ion and less than $1 \%$ of total body magnesium is found in the intravascular compartment [17]. Some studies also found no significant change of serum magnesium. In the last decade several reviews have been concerned with the relevance of $\mathrm{Mg}$ in cardiac disease. Nevertheless, the role of $\mathrm{Mg}$ qualitively and quantitatively is not fully appreciated by most physicians. Serum Mg measurements are not routinely performed. The consequence is that essential data are often lacking. To the best of my knowledge, very few studies have been made on serum magnesium level in acute myocardial infarction in Bangladesh. But it seems to be essential to measure the serum level of $\mathrm{Mg}$ in AMI to improve the management. With this objective the present study will be conducted.

\section{OBJECTIVES OF THE STUDY General}

a) To know the serum magnesium level in patients with acute myocardial infarction.

\section{Specific}

a) To measure serum magnesium level of the patients fulfilling the inclusion criteria

b) To study the incidence of arrhythmia in acute myocardial infarction

c) To study the relation of arrhythmia with serum magnesium level

d) To study the pattern of arrhythmia in cases of hypomagnesaemia.

\section{Materials ANd Methods}

Study design: Descriptive cross sectional study

Place of study: Department of Cardiology, Rajshahi Medical College Hospital, Rajshahi.

Study period: July 2013 to November 2013.

Sample size: 50

Consecutive 50 patients having acute coronary syndrome who fulfill the inclusion and exclusion criteria was enrolled in this study. Sample size is estimated by using following formula-

$\mathrm{n}=\frac{z^{2} p q}{d^{2}}$

$\mathrm{n}=$ the desired sample size

$\mathrm{z}=1.96$ at $95 \%$ confidence level.

$\mathrm{p}=$ prevalence of acute myocardial infarction in the population $3 \%=0.03 .^{18}$

$\mathrm{q}=1-\mathrm{p}=1-0.03=0.97, \mathrm{~d}=0.05$ ( $5 \%$ aceptable error).

According to this formula the estimated final size is going to be 50.]

$\mathrm{d}=$ Degree of accuracy which is considered as 0.05

According to this formula the targeted sample size

$\mathrm{n}=\frac{(1.96)^{2} \times 0.03 \times 0.97}{(0.05)^{2}}=44.716$

Estimated sample size is 50 . (Considering $10 \%$ dropout and exclusion) 


\section{Study population}

All cases of acute myocardial infarction admitted in cardiology ward of Rajshahi Medical college hospital from 5 months of the date of acceptance of protocol.

\section{SAMPLing Method}

Purposive sampling method

Every consecutive clinical case of acute myocardial infarction admitted in $\mathrm{RMCH}$ fulfilling the inclusion criteria was included for the study.

\section{Selection criteria}

Those patients presenting to the hospital within 12 hours of onset of symptoms were taken.

\section{Inclusion criteria}

Patients were considered to have acute myocardial infarction, only if they had two of the following criteria:

- History of chest discomfort

- ECG changes of acute myocardial infarction

- $\quad$ Rise of cardiac enzymes.

\section{Exclusion criteria}

- Patients presenting 12 hours after the onset of chest pain

- Patients with hypokalemia

- Those who are taking diuretics.

\section{Operational Definition}

Acute myocardial infarction [19]:

Either one of the following criteria satisfies the diagnosis for an acute MI.

Typical rise and gradual fall (troponin) or more rapid rise and fall (CK-MB) of biochemical markers of myocardial necrosis with at least one of the followingIschemic symptoms

Development of pathologic Q wave in the ECG

ECG changes indicative of ischemia (ST segment elevation or depression) or

Coronary artery intervention

Pathologic findings of acute MI

\section{Serum magnesium level}

The normal serum magnesium level is approximately $1.6-2.4 \mathrm{mg} / \mathrm{dl}[20]$.

\section{Arrhythmia}

Any abnormal heart rhythm caused by physiological or pathological disturbances in the discharge of cardiac impulses from the sinoatrial node or their transmission through conductive tissue of the heart.

\section{Tachycardia}

A heart rate more than 100 beat/minute
Bradycardia

A heart rate less than 60 beat/minute

\section{Ventricular ectopics (PVC)}

A ventricular extrasystole due to the premature discharge of an ectopic ventricular focus

\section{Ventricular tachycardia}

It may be defined as series of three or more consecutive ventricular ectopic beats which are recorded in rapid succession either extrasystolic or idioventricular form.

\section{Ventricular fibrillation}

It is the expression of chaotic and uncoordinated ventricular depolarization where the biventricular chamber is electrophysiologically fragmented into a mosaic of milling tissue islets in various stages of recovery and excitation.

\section{Supraventricular arrhythmia}

The term used to designate any arrhythmia that originate in the atria or AV junction, when a more specific diagnosis of its mechanism and the site of origin cannot be made, characterized by narrow QRS complex, unless there is pre-existing bundle branch block or aberrant ventricular conduction.

\section{Procedure of preparing and organizing materials}

All collected questionnaire and relevant investigation report was checked very carefully to identify the error in the data. Data processing work was consisting of registration schedules, editing computerization, preparation of dummy table, analyzing and matching of data.

\section{Procedure of data collection}

Data were collected from patients of any age and both sexes with acute myocardial infarction as determined by clinical features, ECG evidence and biochemical report. Blood sample for estimation of serum magnesium level was collected as early as possible within 24 hours of admission and $5^{\text {th }}$ day of admission. After admission to CCU every patient was under continuous cardiac monitoring to see and record any arrhythmia within 5 days onset of symptoms. Detailed history and thorough clinical examination was performed in a prefixed questionnaire form or data collection sheet after taking informed consent of the patients. They were then subjected to a battery of investigations necessary for the patients with acute myocardial infarction and arrhythmia.
Investigations
a) ECG
b) Echocardiogram
c) Troponin I
d) Serum electrolytes
e) Serum magnesium 
f) RBS

g) Serum creatinine

h) Serum lipid profile

\section{Data Analysis}

Socio-demographic and clinical variables: Data for socio- demographic and clinical variables were obtained from all participants by the use of a predesigned and easily understandable questionnaire. After collection of all the data it was entered in the SPSS 16.0 statistical software.

\section{Professional assistance from experts}

Consulted with supervisor and senior teachers with expertise in this topic, statistics and knowledge of ethical matter in research

\section{Procedure of data analysis of interpretation}

The collected answers of the questions analyzed and expressed in No. distribution and parentage, in the form of tables and figures where applicable and corrected to be demographic characteristics of the patients. These have done with the help of SPSS version-16 software.

\section{Quality assurance strategy}

The questionnaire was pre-tested so that respondent will understand easily and answer accordingly. The investigator was making random check of $10 \%$ filled in questionnaires.

\section{Ethical consideration}

Eligibility of each patient was assessed. Patient or responsible family member was asked for informed consent. They were informed about the procedure and study objectives that there was no chance of any harm to the patients by being including in this study. The patient was also informed that they are free to refuse to participate or withdraw at any time without compromising their medical care. Completed data collection form was kept by the principal investigator to which no one had any access.

\section{RESUlTS}

A total of 50 patients of acute myocardial infarction were included during the study period. The male to female ratio in the study group was 3.17:1 and the maximum incidence of acute myocardial infarction was seen in $5^{\text {th }}$ and $6^{\text {th }}$ decade.

Table-1: Age distribution of the study patients $(\mathbf{n}=\mathbf{5 0})$

\begin{tabular}{|l|l|l|}
\hline Age in years & Frequency & Percentage (\%) \\
\hline $30-39$ & 4 & 8.0 \\
\hline $40-49$ & 14 & 28.0 \\
\hline $50-59$ & 24 & 48.0 \\
\hline $60-69$ & 5 & 10.0 \\
\hline $70-80$ & 3 & 6.0 \\
\hline Total & 50 & 100.0 \\
\hline
\end{tabular}

[Table-1] showed the age distribution of the study respondent. Out of 50 cases the maximum incidence of acute myocardial infarction was seen in the $5^{\text {th }}$ and $6^{\text {th }}$ decades $14(28.0 \%)$ and $24(48.0 \%)$, followed by $7^{\text {th }}$ and $8^{\text {th }}$ decades $5(10 \%)$ and $3(6 \%) .4(8 \%)$ patients were in the age group of $4^{\text {th }}$ decade.

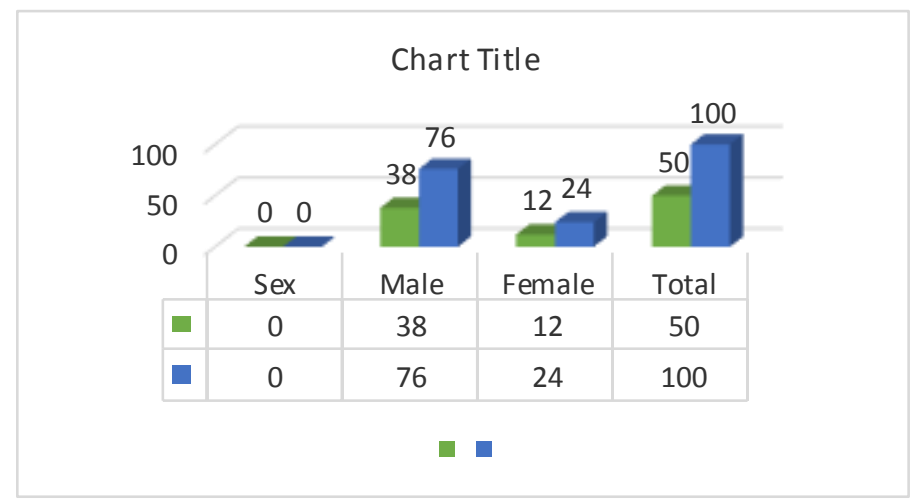

Fig-1: Sex distribution of the study patients $(n=50)$

Above table showed the sex distribution of the study respondent. In this study group of 50 cases,
$38(76.0 \%)$ were males and $12(24.0 \%)$ were female patients with a male-female ratio of 3.17:1 [Figure 2]. 
Table-2: Occupational distribution of the study respondents $(n=50)$

\begin{tabular}{|l|l|l|}
\hline Occupation & No. of cases & Percentage \\
\hline Farmer & 19 & 38.0 \\
\hline Businessman & 10 & 20.0 \\
\hline Service & 9 & 18.0 \\
\hline Housewife & 12 & 24.0 \\
\hline Total & 50 & 100.0 \\
\hline
\end{tabular}

[Table-2] showed the occupational distribution of the study respondent. Among them 19(38\%) patients were farmer, 12(24\%) were housewife, 10(20\%) were businessman and $9(18 \%)$ were service holder.

Table-3: Distribution of the study respondent according to risk factors $(\mathbf{n}=50)$

\begin{tabular}{|l|l|l|}
\hline Risk factors & No. of cases & Percentage \\
\hline Smoking & 35 & 70.00 \\
\hline Family history of premature coronary artery disease & 10 & 20.00 \\
\hline Obesity & 12 & 24.00 \\
\hline Hypertension & 15 & 30.00 \\
\hline Diabetes mellitus & 18 & 36.00 \\
\hline Dyslipidemia & 6 & 12.00 \\
\hline
\end{tabular}

In the study, smoking is the most common $70 \%$ risk factor found in the patients with acute myocardial infarction. In the present study, out of 50 patients, $12(24 \%)$ were found to be obese based on criteria of National Cholesterol Education Programme. Waist circumference was measured in all patients, men whose waist circumference is more than $102 \mathrm{~cm}$ and females whose waist circumference is more than $88 \mathrm{cms}$ were considered to be obese. In the present study, of 50 patients $15(30 \%)$ patients were found to be hypertensive. Patients whose blood pressure is $\geq 140 / 90$ are considered to be hypertensive. In the present study, of the 50 patients, $18(36 \%)$ patients were found to be diabetics and $12(24 \%)$ patients were found to be dyslipidemic. Family history of coronary artery disease found in $10(20.0 \%)$ patients [Table-3].

Table-4: Time of presentation of the study patients $(n=50)$

\begin{tabular}{|l|l|l|}
\hline Time at presentation & No. of cases & Percentage \\
\hline $0-6$ hours & 27 & 54.00 \\
\hline $7-12$ hours & 23 & 46.00 \\
\hline Total & 50 & 100.0 \\
\hline
\end{tabular}

In the present study, 27 (54\%) cases presented to the hospital between $0-6$ hours of onset of symptoms and $23(46 \%)$ cases presented between 7-12 hours [Table-4].

Table-5: Presenting symptoms of study patients $(n=50)$

\begin{tabular}{|l|l|l|}
\hline $\begin{array}{l}\text { Features of } \\
\text { presentation }\end{array}$ & No. of cases & Percentage \\
\hline Chest pain & 50 & 100.0 \\
\hline Sweating & 30 & 60.0 \\
\hline Breathlessness & 32 & 64.0 \\
\hline Palpitation & 25 & 50.0 \\
\hline
\end{tabular}

Above [Table-5] showed the features of presentation to the Hospital. Chest pain was the commonest symptom and was present in all of the patients in the present study (100\%). In this study chest pain was associated with sweating in $30(60 \%)$ of patients. Chest pain was associated with breathlessness in $32(64 \%)$ the patients. Palpitation associated with chest pain was present in 25 patients $(50 \%)$. 


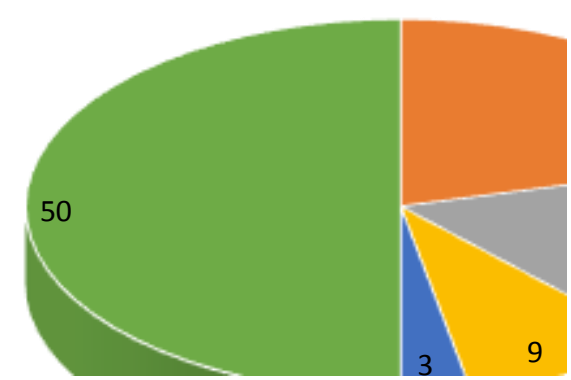

Fig-2: Types of Myocardial Infarction of the study patients ( $n=50)$

Among 50 patients, $21(42 \%)$ patients had anterior wall MI, 17 (34\%) patients had inferior wall
MI, 9 (18\%) patients had anteroseptal MI and 3 (6\%) patients had anterolateral MI [Figure-2].

Table-6: Distribution of patients with arrhythmia in acute myocardial Infarction (n=50)

\begin{tabular}{|l|l|l|}
\hline Type of MI & $\begin{array}{l}\text { Patients with } \\
\text { AMI } \\
(\mathbf{n = 5 0 )} \\
\text { No. (\%) }\end{array}$ & $\begin{array}{l}\text { Patients } \\
\text { arrhythmia } \\
(\mathbf{n = 2 6}) \\
\text { No(\%) }\end{array}$ \\
\hline Anterior wall MI & $21(42 \%)$ & $15(57.7 \%)$ \\
\hline Inferior wall MI & $17(34 \%)$ & $6(23.1 \%)$ \\
\hline Anteroseptal MI & $9(18 \%)$ & $3(11.5 \%)$ \\
\hline Anterolateral MI & $3(6 \%)$ & $2(7.7 \%)$ \\
\hline Total & $50(100.0 \%)$ & $26(100.0 \%)$ \\
\hline
\end{tabular}

Among 50 of acute myocardial infarction, 21(42.0\%) had anterior wall MI of which 15(57.7\%) developed arrhythmia. 17(34\%) patients had inferior wall MI of which $6(23.1 \%)$ developed arrhythmia. Of $9(18 \%)$ anteroseptal MI patients 3(11.5\%) had arrhythmia and of $3(6 \%)$ anterolateral MI patients 2(7.7\%) developed arrhythmia. Above table showed out of 50 patients of acute myocardial infarction $26(52 \%)$ developed arrhythmia [Table-6].

Table-7: Serum magnesium levels in patients with arrhythmias $(\mathrm{n}=\mathbf{2 6})$

\begin{tabular}{|l|l|l|l|l|}
\hline $\begin{array}{l}\text { Serum magnesium levels } \\
\text { (mg/dL) }\end{array}$ & $\begin{array}{l}\text { Day-1 } \\
(\mathbf{n = 2 6})\end{array}$ & Percent & $\begin{array}{l}\text { Day-5 } \\
(\mathbf{n = 2 1})\end{array}$ & Percent \\
\hline$<1.6$ & 9 & 34.6 & 2 & 9.5 \\
\hline 1.6 to 2.40 & 17 & 65.4 & 17 & 81.0 \\
\hline$>2.4$ & - & - & 2 & 9.5 \\
\hline
\end{tabular}

Among 26 patients with arrhythmia $9(34.6 \%)$ had serum magnesium level $<1.6 \mathrm{mg} / \mathrm{dl}$ and $17(65.4 \%)$ had serum magnesium level in between $1.6-2.40 \mathrm{mg} / \mathrm{dl}$ on day-1. Out of 21 patients who developed arrhythmia
$2(9.5 \%)$ had serum magnesium level $<1.6 \mathrm{mg} / \mathrm{dl}$, $17(81.0 \%)$ had level in between $1.6-2.40 \mathrm{mg} / \mathrm{dl}$ and $2(9.5 \%)$ had serum magnesium level $>2.40 \mathrm{mg} / \mathrm{dl}$ on day-5 [Table-7].

Table-8: Serum magnesium levels in patients without arrhythmias $(n=24)$

\begin{tabular}{|l|l|l|l|l|}
\hline Serum magnesium levels (mg/dL) & $\begin{array}{l}\text { Day-1 } \\
(\mathbf{n = 2 4})\end{array}$ & Percent & $\begin{array}{l}\text { Day-5 } \\
(\mathbf{n = 2 3})\end{array}$ & Percent \\
\hline$<1.6$ & 3 & 12.5 & - & - \\
\hline 1.6 to 2.40 & 19 & 79.2 & 14 & 60.9 \\
\hline$>2.4$ & 2 & 8.3 & 9 & 39.1 \\
\hline
\end{tabular}

Among 24 patients without arrhythmia $3(12.5 \%)$ had serum magnesium level $<1.6 \mathrm{mg} / \mathrm{dl}$, $19(79.2 \%)$ had serum magnesium level in between 1.6$2.40 \mathrm{mg} / \mathrm{dl}$ and $2(8.3 \%)$ had level $>2.4 \mathrm{mg} / \mathrm{dl}$ on day-1.
Out of 23 patients without arrhythmia 14(60.9\%) had serum magnesium level in between $1.6-2.40 \mathrm{mg} / \mathrm{dl}$ and $9(39.1 \%)$ had level $>2.40 \mathrm{mg} / \mathrm{dl}$ on day-5 [Table-8]. 
Table-9: Mean serum magnesium level in Day 1 and Day $5(n=50)$

\begin{tabular}{|l|l|l|}
\hline & Day-1 & Day-5 \\
\hline Mean serum magnesium in 50 cases & $1.86 \pm 0.39$ & $2.26 \pm 0.50$ \\
\hline Mean serum magnesium level in patients with arrhythmia & $1.65 \pm 0.26$ & $1.98 \pm 0.25$ \\
\hline
\end{tabular}

In this cross sectional study of 50 patients, the mean serum magnesium level on day-1 in all 50 patients was $1.86 \pm 0.39$ and the mean serum magnesium level on day-5 was $2.26 \pm 0.5$. In the present study, out of 50 patients 26 patients had significant ventricular premature contractions/ ventricular tachycardia/ ventricular fibrillation during their 5-days course in the hospital. The mean serum magnesium level in this group on day-1 was $1.65 \pm 0.26$ and day-5 was $1.98 \pm 0.25$ [Table-9].

Table-10: Comparison of Serum Magnesium level in patients with Arrhythimas and without Arrhythmias (Day-1)

\begin{tabular}{|l|l|l|l|l|}
\hline \multicolumn{1}{|c|}{$(\mathbf{n = )})$} & $\begin{array}{l}\text { No. of } \\
\text { cases }\end{array}$ & $\begin{array}{l}\text { Serum } \\
\text { magnesium } \\
\text { Day-1 }\end{array}$ & t- value & p-value \\
\hline Mean serum magnesium level in patients with arrhythmia & 26 & $1.65 \pm 0.26$ & 4.28 & $<0.001 *$ \\
\hline Mean serum magnesium level in patients without arrhythmia & 24 & $2.08 \pm 0.41$ & 48 \\
\hline
\end{tabular}

Data were analyzed by using independent student t-test, $*=$ Significant

The above [Table-10] shows that out of 50 patients, 26 patients had arrhythmias. The mean value of serum magnesium on day-1 those with arrhythmias is $1.65 \pm 0.26$ those without arrhythmias is $2.08 \pm 0.41$ $(\mathrm{p}<0.001)$. There is a significant difference in the magnesium level in patient with arrhythmias and without arrhythmias.

Table-11: Comparison of Serum Magnesium level in patients with Arrhythimas and without Arrhythmias (Day-5)

\begin{tabular}{|c|c|c|c|c|}
\hline & No. of cases & $\begin{array}{l}\text { Serum } \\
\text { magnesium } \\
\text { Day-5 }\end{array}$ & t- value & p-value \\
\hline $\begin{array}{l}\text { Mean serum magnesium level in patients with } \\
\text { arrhythmia }\end{array}$ & 21 & $1.98 \pm 0.25$ & \multirow{2}{*}{4.14} & \multirow{2}{*}{$<0.001$} \\
\hline $\begin{array}{l}\text { Mean serum magnesium level in patients } \\
\text { without arrhythmia }\end{array}$ & 23 & $2.48 \pm 0.52$ & & \\
\hline
\end{tabular}

Data were analyzed by using independent student t-test, $*=$ Significant

The above [Table-11] shows that serum magnesium in patient with arrhythmia on Day-5 is $1.98 \pm 0.25$ those without arrhythmia is $2.48 \pm 0.5$. There is a significant difference between these two $(\mathrm{p}<0.001)$. Mortality: In the above study out of 50 patients, 6 patients died during their 5 days hospital course. 4 patients died of ventricular tachycardia and ventricular fibrillation, 2 patients died of cardiac arrest. Mortality percentage was $12 \%$.

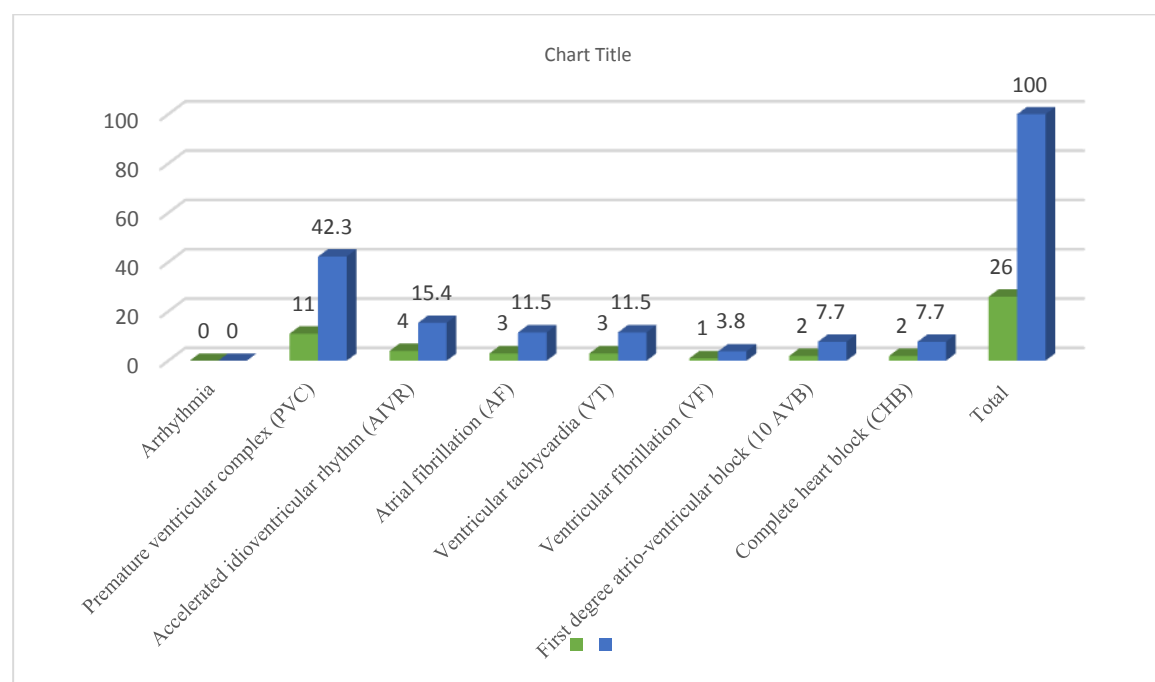

Fig-3: Distribution of pattern of arrhythmia in patients with acute myocardial infarction $(n=26)$ 
Study showed PVC occurred in 11 patients which was the most common (42.3\%) arrhythmia among 26 acute MI patients who developed various arrhythmias during their 5 day course in hospital [Figure 3].

\section{DISCUSSION}

Heart disease is the lethal cause of death and is more common in adult male. In the present study maximum number of cases of acute myocardial infarction were in the age group 50 to $59(48 \%)$ and the cases were predominately male $(76 \%)$ suggesting that it is predominately a disease of men. Yadav $\mathrm{P}$ et al. [21] showed that Acute MI is more common in 51-60 (32\%) age group \& in male (72\%) which is similar to this study. There are many modifiable and non-modifiable risk factors of coronary heart disease. The role and relative importance of many risk factors for the development of coronary, peripheral and cerebrovascular disease have been defined in experimental animal studies, epidemiological studies and clinical interventional trials. The effect of risk factors is multiplicative rather than additive. People with a combination of risk factors are at greatest risk and so assessment should take account of all identifiable risk factors. The present study showed that commonest risk factors in Acute MI were smoking (70\%), DM (36\%), hypertension (30\%), Obesity (24\%), hyperlipidemia (12\%). In Steg PG [21] study they found that commonest risk factors in Acute MI were smoking (62\%), hypertension $(50 \%)$, DM (21\%), Prior infarction (19\%), hyperlipidemia (35\%) which is very close to the current study. Kelly A.M. et al. [22] showed that family history contributes $25 \%$ risk of ACS. Whereas present study showed $20 \%$ reflecting the similar risk. Pain is the cardinal symptom of an acute myocardial infarction but breathlessness, sweating, vomiting, and collapse, palpitation are also common features. The pain occurs in the same sites as angina but is usually more severe and lasts longer; it is often described as a tightness, heaviness or constriction in the chest. In acute MI, the pain can be excruciating, and the patient's expression and pallor may vividly convey the seriousness of the situation. The present study showed that among the acute MI patients the commonest symptoms were chest pain $(100 \%)$, sweating (60\%), breathlessness (64\%), and palpitation (50\%). Yadav $\mathrm{P}$ et al. [23] showed the commonest symptoms were chest pain (94\%), sweating (78\%), breathlessness (67\%), and palpitation (58\%) which is very similar with the present study. Complications are commonly seen in all forms of acute myocardial infarction, although the frequency and extent vary with the severity of ischemia and infarction. Major mechanical, structural and electrical complications are seen with significant, often transmural infarction. Misiriya R.K.J et al. [24] found that among the patients with acute MI, 50\% had inferior wall, $43.97 \%$ had anterior wall infarctions, $6.03 \%$ had lateral wall and isolated posterior wall infarctions. The present study showed $42 \%$ had anterior wall infarctions, $34 \%$ had inferior wall infarctions, $18 \%$ had anteroseptal wall infarctions and $6.0 \%$ had lateral wall infarction. Present study showed of $57.7 \%$ of the total anterior wall MI patients developed arrhythmia in their 5 days stay in hospital. Arrhythmia developed in $23.1 \%$ of inferior wall MI patients, $11.5 \%$ and $7.7 \%$ of anteroseptal and anterolateral MI patients respectively. In the present study of 50 patients, the mean serum magnesium level on day- 1 in all 50 patients was $1.86 \pm 0.39$ and the mean serum magnesium level on day-5 was 2.26 \pm 0.5 . Abraham et $\mathrm{al}^{25}$ reviewed magnesium level of 65 consecutive patients with an admission diagnosis of acute myocardial infarction. Serum magnesium concentration were low in patient who had AMI (mean $1.70 \mathrm{mg} / \mathrm{dl}, \mathrm{p}<0.001)$ or acute coronary insufficiency (mean $1.61 \mathrm{mg} / \mathrm{dl}, \mathrm{p}<0.01$ ), but not in the control group or patients with non-cardiac chest pain (mean 1.91 $\mathrm{mg} / \mathrm{dl}$ ). Sachadeva et al. [26] (1978) in 30 patients of myocardial infarction determine the magnesium levels within 24 hours, $5^{\text {th }}$ and $8^{\text {th }}$ day and reported as $1.83 \pm 0.087 \mathrm{mgm} \%, 1.91 \pm 0.149$ and $1.97 \pm 0.089$ as against control of $2.44 \pm 0.162 \mathrm{mgm} \%$. The values were statistically lower on all the three days showing a progressive rise which is similar to the present study. In the present study, the serum magnesium level on day-1 was significantly lower (mean1.65 \pm 0.26 ) in patients with arrhythmias than those without arrhythmia $($ mean2.08 \pm 0.41$)(\mathrm{p}<0.001)$. There was an increase in serum magnesium from Day-1 to Day-5 in both those with arrhythmias (mean $1.98 \pm 0.25$ ) and those without arrhythmias (mean2.48 \pm 0.52 ) and the difference in both group is significant $(\mathrm{p}<0.001)$. Misiriya R.K.J et al. [24] found that in STEMI commonest arrhythmia encountered was premature ventricular complex (PVC) $40.04 \%$. Other arrhythmias observed were accelerated idioventricular rhythm (AIVR) 18\%, ventricular tachycardia (VT) $13.98 \%$. Misiriya R.K.J et al. [24] found that in acute MI commonest arrhythmia encountered was atrial fibrillation (AF) $8.05 \%$ and ventricular fibrillation (VF) $5.36 \%$ patients. The present study showed commonest arrhythmia was PVC $42.3 \%$, $\mathrm{AF}$ and VT $11.5 \%$, AIVR $15.4 \%$ and $\mathrm{CHB} 7.7 \%$. Dyckner $\mathrm{T}$ et al. [27] during their 11/2 years, 905 admission, 342 with acute myocardial infarction, 563 other diagnoses were treated in the $\mathrm{CCU}$ on admission both acute myocardial infarction and non AMI group had significantly lower serum magnesium level than as reference group. The incidence of serious ventricular premature beats, ventricular tachycardia and ventricular fibrillation on admission was significantly higher in the hypomagnesemic patients with acute myocardial infarction which is similar to the present study.

\section{Conclusion}

This study was carried out in 50 patients of acute myocardial infarction who are admitted to the 
Department of Cardiology, Rajshahi Medical College Hospital, Rajshahi, Bangladesh. The male to female ratio in the study group was 3.17:1 and the maximum incidence of acute myocardial infarction was seen in $5^{\text {th }}$ and $6^{\text {th }}$ decade. In the study, the most common presentation symptom was chest pain and is associated with sweat in $60 \%$ of patients and breathlessness in $64 \%$ of patients and palpitation in $50 \%$ patients. In the study, the most common risk factor found was smoking followed by diabetes and hypertension. Anterior wall MI was found to be the most common type of MI (42\%) and arrhythmia occurred in $57.7 \%$ patients with anterior wall MI. In the study group mean serum magnesium level in 50 patients on day- 1 is $1.86 \pm 0.39$ and on Day-5 is 2.26 \pm 0.5 . Mean serum magnesium level in 26 patients with arrhythmia was $1.65 \pm 0.26$ on day- 1 and $1.98 \pm 0.25$ on day-5. In the study group, mean serum magnesium level in 24 patients without arrhythmia was $2.05 \pm 0.41$ on day- 1 and $2.48 \pm 0.52$ on day-5. The difference between the magnesium level in patients with arrhythmia and without arrhythmia is statically significant on both day- 1 and day-5(p<0.001). PVC was the most common type $(42.5 \%)$ of arrhythmia.

\section{LIMITATIONS AND \\ RECOMMENDATION}

The study was carried out in a single centre with small sample volume. There was no control group. So the conclusion of the study should not be considered absolute and further multicentre study with large sample volume is needed.

- Further Larger Scale study may be conducted.

- Serum magnesium level may be done as a routine investigation in all patients who present with acute myocardial infarction.

- Continuous cardiac monitoring should be undertaken for every patient with acute MI as early as possible after admission into CCU to identify any cardiac arrhythmia early so that definite treatment and preventive measures can be taken promptly.

\section{REFERENCES}

1. Moran, A. E., Forouzanfar, M. H., Roth, G. A., Mensah, G. A., Ezzati, M., Flaxman, A., ... \& Naghavi, M. (2014). The global burden of ischemic heart disease in 1990 and 2010: the Global Burden of Disease 2010 study. Circulation, 129(14), 14931501 .

2. Khondokar, R. K., Hossain, D., \& Hossain, M. (1987). Retrospective analysis of acute myocardial infarction. Bang Heart J, 1, 14.

3. Islam, M. N., Ali, M. A., \& Ali, M. (2004). Spectrum of cardiovascular disease: the current scenario in Bangladesh. Bangladesh Heart Journal, 19(1), 1-7.

4. Bunton, R. W. (1983). Value of serum magnesium estimation in diagnosing myocardial infarction and predicting dysrhythmias after coronary artery bypass grafting. Thorax, 38(12), 946-950.

5. Jeremias, A., Bertschat, F. L., Ising, H., \& Jeremias, E. (2000). Possible correlation between decrease of ionized magnesium and calcium in blood to patient outcome after acute myocardial infarction. Journal of Clinical and Basic Cardiology, 3(2), 123-128.

6. Wacker, W. E., \& Parisi, A. F. (1968). Magnesium metabolism. New England Journal of Medicine, 278(14), 772-776.

7. Ebel, H., Günther, T. (1983). Role of Magnesium in Cardiac Disease J. Clin. Chem. Clin. Bipchem, 21: 249-265

8. Whang, R., Chrysant, S., Dillard, B., Smith, W., \& Fryer, A. (1982). Hypomagnesemia and hypokalemia in 1,000 treated ambulatory hypertensive patients. Journal of the American College of Nutrition, 1(4), 317-322.

9. Antman, E. M. (1995). Magnesium in acute MI: timing is critical. Circulation, 92(9), 2367-2372.

10. Hussain, Z., Tanvir, Z. H., \& Ahmad, A. (2010). Acute myocardial infarction. The Professional Medical Journal, 17(02), 246-251.

11. Hussain, Z., Tanvir, Z. H., \& Ahmad, A. (2010). Acute myocardial infarction. The Professional Medical Journal, 17(02), 246-251.

12. Ahmad, A., Tanvir, Z.H., Hussain, Z. (2010). Acute myocardial infarction; Serum magnesium and electrolyte levels at presentation in emergency department. Professional Med J. 17(2): 246-251.

13. Autman, E.M. (1996). Magnesium in acute myocardial infarction: Overview of the available evidence. Is heart J. 132: 487-494?

14. Abraham, A., Shaoul, R., Shimonovitz, S. (1980). Serum magnesium levels in Acute Medical and Surgical Conditions. Biochemical Medicine. 24: 21

15. Babel, S., Bhatnagar, H. N., \& Bhatnagar, L. K. (1983). Serum magnesium levels in cases of acute myocardial infarction and its prognostic significance. The Journal of the Association of Physicians of India, 31(12), 755.

16. Choudhury, M. B. K., Rahman, M. S., Hassan, M. M., Begum, R., Hoque, N., Akhtaruzzaman, M., \& Chowdhury, A. N. (2011). Comparison of serum magnesium and potassium in acute myocardial infarction and chronic ischemic heart disease. Journal of Dhaka National Medical College \& Hospital, 17(1), 33-36.

17. Haigney, M. C., Silver, B., Tanglao, E., Silverman, H. S., Hill, J. D., Shapiro, E., ... \& Schulman, S. P. (1995). Noninvasive measurement of tissue magnesium and correlation with cardiac levels. Circulation, 92(8), 2190-2197.

18. Gupta, R., Joshi, P., Mohan, V., Reddy, K. S., \& Yusuf, S. (2008). Epidemiology and causation of coronary heart disease and stroke in India. Heart, 94(1), 16-26. 
19. French, J. K., \& White, H. D. (2004). Clinical implications of the new definition of myocardial infarction. Heart, 90(1), 99-106.

20. Dyckner, T. (1980). Serum magnesium in acute myocardial infarction: relation to arrhythmias. Acta Medica Scandinavica, 207(1- 6), 59-66.

21. Steg, P. G., Goldberg, R. J., Gore, J. M., Fox, K. A., Eagle, K. A., Flather, M. D., ... \& GRACE Investigators. (2002). Baseline characteristics, management practices, and in-hospital outcomes of patients hospitalized with acute coronary syndromes in the Global Registry of Acute Coronary Events (GRACE). The American journal of cardiology, 90(4), 358-363.

22. Kelly, A. M., \& Klim, S. (2011). How common are ventricular arrhythmias in patients admitted to CCU with chest pain and a non-ischaemic ECG? A pilot study. Heart Asia, 3(1), 48-50.

23. Yadav, P., Joseph, D., Joshi, P., Sakhi, P., Jha, R. K., \& Gupta, J. (2010). Clinical profile \& risk factors in acute coronary syndrome. National $J$ Comm Med, 1(2), 150-151.

24. Misiriya, K. J., Sudhayakumar, N., Khadar, S. A., George, R., Jayaprakasht, V. L., \& Pappachan, J. M. (2009). The clinical spectrum of acute coronary syndromes: experience from a major center in Kerala. J Assoc Physicians India, 57, 377-83.

25. Abraham, A. S., Shaoul, R., Shimonovitz, S., Eylath, U., \& Weinstein, M. (1980). Serum magnesium levels in acute medical and surgical conditions. Biochemical medicine, 24(1), 21-26.

26. Sachdeva, J. R., Kumar, A., \& Chander, J. (1978). Serum magnesium levels and platelet adhesiveness in acute myocardial infarction. Journal of the Indian Medical Association, 71(7), 165.

27. Dyckner, T. (1980). Serum magnesium in acute myocardial infarction: relation to arrhythmias. Acta Medica Scandinavica, 207(1- 6), 59-66. 